\title{
Band Form Granulocyte to Total Cell Ratio Measurement
}

National Cancer Institute

\section{Source}

National Cancer Institute. Band Form Granulocyte to Total Cell Ratio Measurement. NCI

Thesaurus. Code C127615.

The determination of the ratio of band form granulocytes compared to total cells present in a sample. The measurement may be expressed as a ratio or percentage. 